\title{
Enhancement stability and color fastness of natural dye: A review
}

https://doi.org/10.1515/eng-2021-0055

Received Aug 27, 2020; accepted Feb 19, 2021

\begin{abstract}
Consumer awareness of the adverse biological effects of synthetic dyes makes the demand for commercial foods and drinks with natural ingredients increase. The use of natural dyes is increasing and is in demand by consumers in the industrial world. Natural dyes have been used in several sectors such as food, clothing, arts, coatings, and energy. The low stability and brightness of the natural red color are affected by exposure to light, temperature, $\mathrm{pH}$ and etc. The co-pigmentation process makes the stability and brightness of natural dyes. The copigmentation method is known that there are two type, liquid and powder. In addition, the combination of copigmentation additives and the correct configuration of the spray dryer process can increase quality color fastness and stability.
\end{abstract}

Keywords: Natural dye, color stability, color fastness, copigmentation, spray dryer

\section{Introduction}

Color is very important because it is one of the characteristics of the first time by consumers. Consumer demand for commercial food and drinks with the use of natural ingredients has increased. This makes the need for dyes in the industry is very large. This makes a product can attract consumers to buy it. The development of natural dyes has been carried out in the food sector [1-4], clothing [5, 6], art [7, 8], coating [9], and energy [10, 11]. Natural coloring applications are increasingly being considered by consumers. Con-

\footnotetext{
`Corresponding Author: Zainal Arifin: Department of Mechanical Engineering, Faculty of Engineering, Universitas Sebelas Maret, Jl. Ir. Sutami 36A, Surakarta, Indonesia; Email: zainal.arifin@staff.uns.ac.id

Catur Harsito: Department of Mechanical Engineering, Vocational School, Universitas Sebelas Maret, Jl. Ir. Sutami 36A, Surakarta, Indonesia

Aditya Rio Prabowo, Singgih Dwi Prasetyo: Department of Mechanical Engineering, Faculty of Engineering, Universitas Sebelas Maret, Jl. Ir. Sutami 36A, Surakarta, Indonesia
}

Ә Open Access. ๑ 2021 C. Harsito et al., published by De Gruyter. (cc) BY License sumer awareness of synthetic dyes is increasingly abandoned because of their adverse effects on biologics [12]. This makes producers and research on natural dyes have increased.

Some natural dyes have lacks in terms of color stability and brightness that are affected by light exposure, temperature, $\mathrm{pH}$, etc. Color derived from anthocyanin has a low color stability when exposed to light and also temperature [13]. In addition, consumers prefer products with brighter colors. So, we need an alternative to increasing the brightness and color stability of natural dyes products. There are several ways to improve color stability, one of which is co-pigmentation.

In the clothing sector, the quality of natural dyes derived from Caesalpinia Sappan L. extract has been investigated for its stability and has succeeded in increasing colorfastness by adding chitosan [6]. The use of purple carrot extract as a beverage coloring agent has a color storage stability for 5 days [1]. The dye from blackberry extract which is then made into powder using the spray dryer method is mixed with maltodextrin [14]. The addition of maltodextrin can improve the quality of natural dyes by microencapsulation [15]. Prasetyo et al. made a red dye from Secang wood (Caesalpinia Sappan L.) using a spray dryer method to produce an unattractive powder dye which is dark red [5]. The spray dryer process needs to observe the effect of the liquid flow velocity and also the temperature of the inlet [16]. In addition to the spray drying method, mat drying can also be done to make a coloring powder from beetroot (Beta vulgaris) [17]. The use of the freeze-drying method by encapsulating dyes has also been carried out by Dag (2017) to determine the most appropriate compound for encapsulating Goldenberry [18]. The use of the co-pigmentation method to increase the red color of wine added to caffeic acid can make the wine color attractive in the package [2]. Mariot (2018) to do research on improving the color stability of red tomatoes using Arabic Gum [3]. Color stability will be very sensitive to temperature and light exposure. Sappan Wood red color stability under storage conditions has been investigated in a liquid state with $\mathrm{pH}$ and temperature $90^{\circ} \mathrm{C}$ by Ngamwonglumlert (2002) [19]. In addition to the use of Gum Arabic, the co-pigmentation process can be 
Table 1: Pigments in plants [34]

\begin{tabular}{cll}
\hline Pigment & Common type & Occurrence \\
\hline Betalains & Betacyanin's Betaxanthins & Caryophyllales and some fungi \\
Carotenoids & Carotenes & Photosynthetic plants and bacteria \\
& Xanthophylls & Retained from the diet by some birds, fish and crustaceans \\
Chlorophyll & Chlorophyll & All photosynthetic plants \\
Flavonoids & Anthocyanins & Widespread and common in plants including angiosperms, gym- \\
& Aurones & nosperm's, ferns and bryophytes \\
& Chalcones & \\
& Flavanols & \\
& Proanthocyanidins & \\
\hline
\end{tabular}

carried out using Maltodextrin (MD)/Dextrose Equivalent (DE)/Soluble Starch (SS) [8].

To find out the value of the color changes that occur, it is necessary to conduct a comprehensive colorimeter study on the co-pigmentation method and also look at the factors that influence the available processes [20]. Natural color degradation that occurs due to some of the things mentioned above, Jiang (2019) conducted a study of the effect of heat treatment carried out on purple sweet potato extract by adjusting pH 3-7 [21]. Díaz-Sánchez (2006) identify the stability of the red color of pears during heat treatment [22]. Co-pigmentation can also produce good color brightness under liquid dye conditions. Moser (2017) using a mixture of maltodextrin and protein in the spray drying process can increase the brightness of the dye powder from Grape [23]. In the food sector, the use of the red cactus pear powder encapsulation method is carried out at high temperatures [4] In addition to the colorimeter study, there are also parameters that indicate the value of the color change and that is by looking at the refractive index properties. The addition of co-pigment material that has a high refractive index value can affect the brightness of natural dyes. Akhtar (2017) conducted a study on the use of $\mathrm{ZnS}$ material to control the value of the refractive index [24]. In addition, the addition of $\mathrm{Fe}_{2} \mathrm{O}_{3}$ material that has a refractive index value of more than 2 can increase the refractive index value of $\mathrm{ZnO}$ [25]. The refractive index value is very dependent on the texture of the material's morphological film [26]. This paper will discuss the methods used to increase stability and enhance natural dyes. This will provide an overview of the development of natural dyes that consumers are interested in.

\section{Natural Dye}

Color is the energy produced from light that moves at high speed and has a certain wavelength value $(\lambda)$. The electron structure of the pigments that interact with sunlight changes the length of the waves that are transmitted or reflected. The use of natural dyes is increasingly being considered by consumers and consumer awareness of synthetic dyes is increasingly being abandoned because it has a bad biological effect [12]. Natural dyes come from the extraction of leaves, stems, bark, or plant flowers. There are several colors that have been investigated, namely blue (Indigofera tinctoria), green (papaya leaf chlorophyll), red (Caesalpinia Sappan L.), yellow (Turmeric, Cudrania Javanensis), brown (Ceriops Tagal), and others [27-31]. In plants, common structures such as Carotenoids, Belatians, Chlorophyll, and Flavonoids are structures that produce color show in Table 1. Identification of colors can be done by reviewing the maximum wavelength [32].

Dyes in powder form can increase the storage time and can facilitate various applications. The manufacture of coloring powders uses a drying method derived from liquid / extracted wood extracts which is then sprayed together with gas so that it becomes like steam or can be called fogging [33]. Water vapor sprayed into the room with high temperatures causes the water contained in the extract to evaporate and produce small particles which are then flowed and displayed in a cyclone container as a place for the coloring of the powder.

\subsection{Carotenoids}

The color produced from carotenoids comes from several flowers and fruits in red, orange, yellow which are determined by the number of aromatic carotenoids compounds [34]. The resulting color is produced with vari- 
ous simple structural modifications of the polygene chain. These carotenoids have a color absorption area at weak wavelengths of chlorophyll and serve as a protection from excessive light causing color changes [32].

\subsection{Flavonoids}

Flavonoids are structures formed from 15 carbon chains with two phenyl rings and three carbons that bridge and form rings, colors varying based on the oxidation level of the $\mathrm{C}$-ring but not all flavonoids are able to produce colors in the visible light spectrum region and are characterized by electrons loosely charged or even unattached. Color formation in flavonoids is divided into three basic components: the primary structure of flavonoids, the secondary structure formed by $\mathrm{pH}$, and the tertiary structure formed due to interactions between molecules or intermolecular themselves [35].

\subsection{Anthocyanin}

Anthocyanin is a type of flavonoids derived from flowers, fruits, and leaves of angiosperms which gives elements of various colors ranging from salmon pink to red and purple to dark blue and resides in other plant tissues such as tubers, roots, and stems [36]. The colors produced by anthocyanin in plants are red, yellow, and also brown [5]. Some colors produced by anthocyanin have poor color resistance to temperature and light.

\subsection{Co-pigmentation}

Co-pigmentation is one way to produce a stable color or color change due to the colorless cofactor reaction that binds to anthocyanin to form a sheath. This gives a bathochromic and hypochromic effect. The bathochromic and hypochromic effects can be proven by testing using a UV-Vis spectrophotometer. Bathochromic is the shifting value of $\lambda$ max at a specific wavelength can be formulated with $\Delta \lambda=\lambda 2-\lambda 1$. While hypochromic is increasing the peak absorbance value in the visible range that is formulated with $\Delta \mathrm{A}=\mathrm{A} 2-\mathrm{A} 1[37,38]$. In addition, co-pigmentation is a molecular interaction between anthocyanin and other molecules that can cause changes in the color and stability of anthocyanin.

Co-pigmentation can be done with several materials such as ferulic acid, routine, maltodextrin, caffeic acid, catechin, gum arabic, acetic acid, phenolic, gallic acid, pro- tein, alginate, and pectin. Addition of Arabic Gum as much as (0-5\%) as a co-pigment dissolved in deionized water and then stir until hydrated and maintained at $\mathrm{pH} 3$ conditions. In the liquid phase, caffeic acid and catechin are added as much as $120 \mathrm{ml} / \mathrm{g}$ to the fermentation process with a temperature of $24^{\circ} \mathrm{C}$ for three days, then the color stability is measured with susceptibility 30 days, 90 days, and 210 days after fermentation. In addition, the addition of gallic, ferulic, and caffeic acids was carried out on purple yam extract using $0.01 \%$ methanol $\mathrm{HCl}$ as a solvent for 2 hours. Mixing method by means of preparation in liquid form has also been carried out for red wine with the influence of the amount of co-pigment, temperature of the preparation, and also the $\mathrm{pH}$ of the co-pigmentation.

Co-pigmentation can be done by spray dryer method, the use of fermentation of ferulic acid and routinely mixed in the extraction process of blackberries with a composition of 1:1 (blackberry: co-pigment) in the molar fraction. Then maltodextrin is added to the adjusted composition to produce a final result of $6 \mathrm{~g} / 100 \mathrm{~g}$ from the input solution. Combination of addition of maltodextrin, dextrose equivalent 11-15, arabic gum with MD:GA (60:40) mixed until dissolved. On the other hand, the dye is macerated for 24 hours at room temperature. Furthermore, it is mixed into an emulsion and atomized using a spray dryer with a centrifugal atomizer flow rate method of 9.5\%. Fei Lao et al. use nitrogen in the spray dryer process to produce powder dyes. Nitrogen is pumped with a flow rate of $35 \mathrm{~m}^{3} / \mathrm{h}$ and the pigment solution is set at $1.5 \mathrm{~mL} / \mathrm{min}$. The inlet temperature is set to constant at $130^{\circ} \mathrm{C}, 150^{\circ} \mathrm{C}$, and $170^{\circ} \mathrm{C}$.

To increase the brightness of the colors, the spray drying process of the grape juice solution mixed with maltodextrin and protein applies the following conditions:

1. Grape is extracted at $75-85^{\circ} \mathrm{C}$ for 60 minutes (until brix $14 \pm 0.1 \mathrm{pH} 3.84)$.

2. Maltodextrin and soy protein are mixed by agitation method. Then the spray drying process is carried out with a temperature of $140^{\circ} \mathrm{C}$, a solution flow rate of $2 \mathrm{~mL} / \mathrm{min}$, and a water flow of $500 \mathrm{~L} / \mathrm{h}$ with a 0.7 $\mathrm{mm}$ orifice type nozzle. The extraction method can also be done by heating for $5 \mathrm{~s}$ at $80^{\circ} \mathrm{C}$ then cooled rapidly at $8-10^{\circ} \mathrm{C}$. Then do the pollination with an inlet temperature of $150^{\circ} \mathrm{C}$ and an outlet temperature of $90^{\circ} \mathrm{C}$.

The way of encapsulation can also be done by freezedry at a temperature of $-50^{\circ} \mathrm{C}$ which can produce soft powder. Previously, the solution was added with maltodextrin, gum arabic, alganite and pectin to get a long shelf life of juice. 


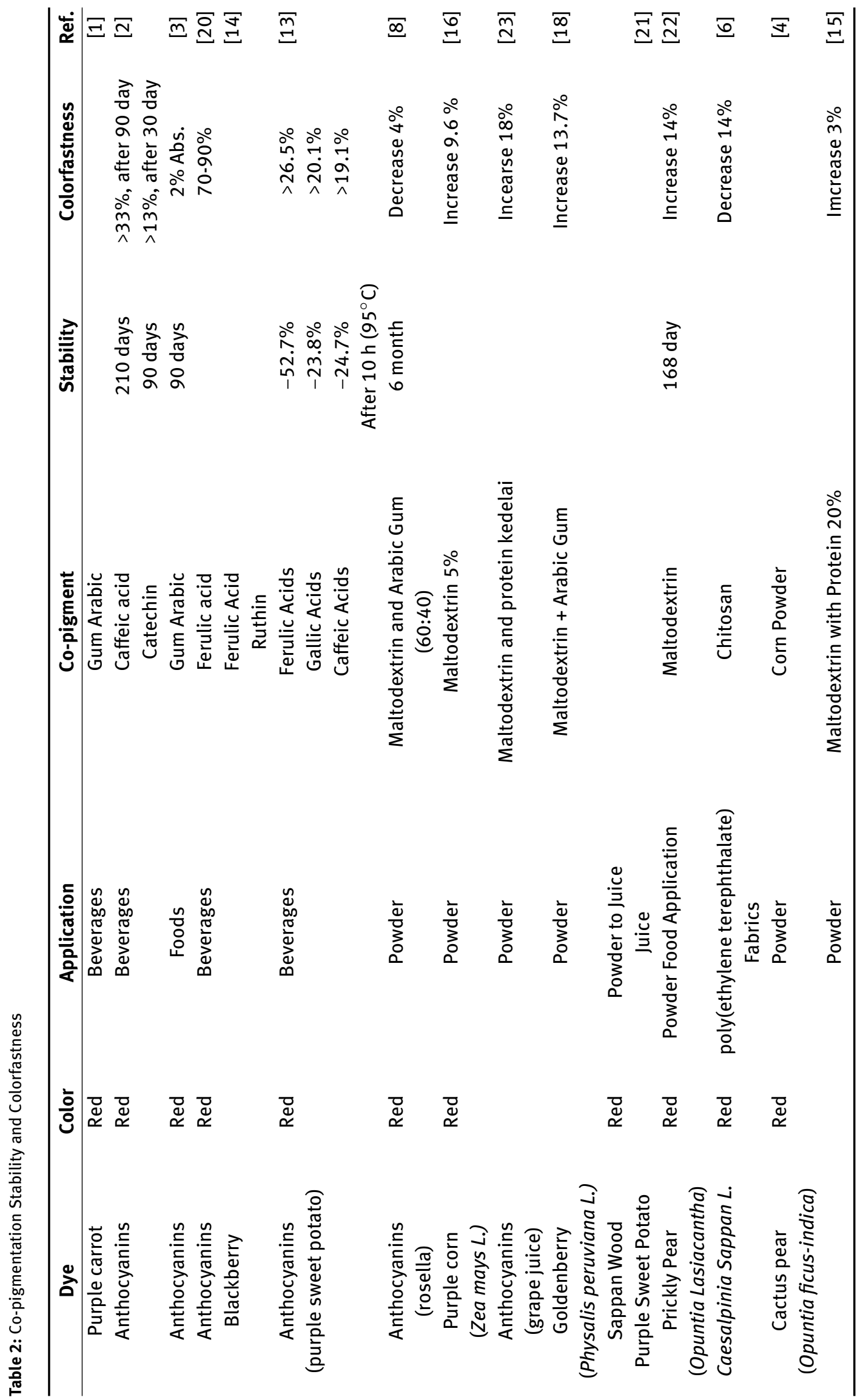




\subsection{Spray Dryer}

The use of the first powder manufacturing method is used in the production of milk powder, the method used is a spray dryer where this method serves to encapsulate all functional compounds. In several studies, this method has been successfully applied to natural dyes from various sources, besides this method is more effective and inexpensive [31]. The powder of the spray dryer process is influenced by several factors namely the physical properties of the material, the condition of the nozzle, the temperature of the inlet and outlet, the solvent, and other factors [39]. Figure 1 shows a schematic spray dryer machine for producing powder dyes.

Improving the color quality can be done by adjusting the condition of the spray dryer process. Temperature control of inlet, bulk and outlet can affect the morphology of the powder that has been given microencapsulation. Emulsions at $45^{\circ} \mathrm{C}$ flow into a spray dryer system with a feed flow rate of $30 \mathrm{~mL} \mathrm{~min}^{-1}$ and the inlet temperature is set at $190^{\circ} \mathrm{C}$.

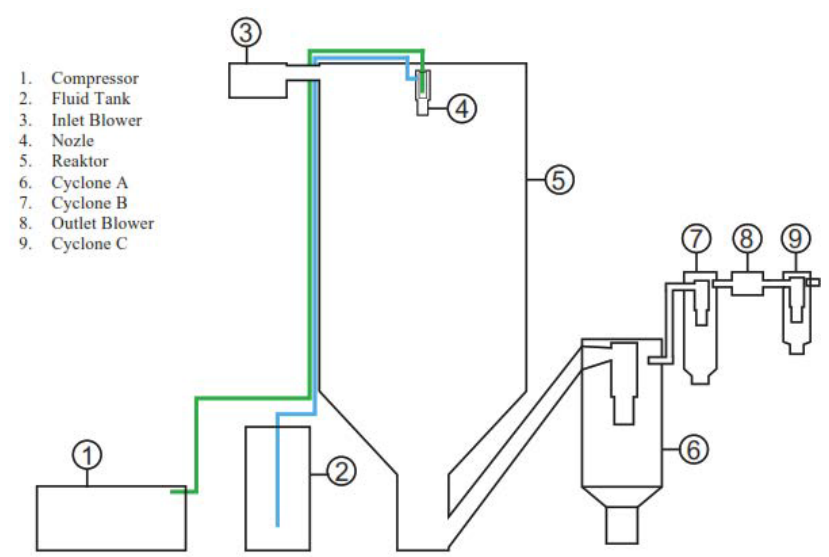

Figure 1: Schema of Spray Dryer Machine [5].

\section{Discussion}

The use of natural ingredients as dyes, especially red, is mostly applied in liquid form and also some in powder form. Color stability and color brightness resulting from natural colors that are less attractive to consumers in terms of commercial products are very urgent issues for research. The addition of Arabic gum to beverages affects the color stability of anthocyanin to be better because of slower color changes. This increase in stability is influenced by the interaction between anthocyanins and glycoprotein fractions on the Arabic gum molecule that is linked to form hydrogen bonds [40]. In addition, the color enhancement due to caffeic acid helps more dissolved color-carrying anthocyanins in the form of flavonoid or non-flavonoid phenols [41]. Degradation of anthocyanin monomers is faster with fading color, whereas self-stacking anthocyanins are assumed to have higher heat resistance than co-pigmentation with phenolic acids through overlap. So that phenolic acid disturbs anthocyanin for self-association. The liquid copigmentation dye produces a brighter color. The additional material used also affects the brightness of the color.

In the beverage model, the addition of phenolic copigmentation (p-hydroxybenzoic acid, protocatechuic acid, vinylic acid, p-coumaric acid, caffeic acid, ferulic acid, vinylic aldehyde, and coniferyl aldehyde) also gives effect to the color change. The addition of ferulic acid with a molarity ratio of 1: 100 gave a high color change. Meanwhile, complex co-pigmentation is successfully formulated at low temperature around $10-20^{\circ} \mathrm{C}$. Color change due to $\mathrm{pH}$ was found at $\mathrm{pH} 3.0$ with yield variations. The addition of copigments in a liquid state results in poor color fastness. However, along with the development of research, the combination of copigmentation materials can increase color resistance.

The addition of Maltodextrin (MD) dextrose equivalent (DE) 11-15, gum arabic, combination of MD and GA (60:40) with soluble starch (SS) in roselle extract produces a brighter red color and lasts for 6 months in the dark. After 6 months, the reddish color changes due to anthocyanin degradation during storage. This change is identified by observing the content of the pigment betacyanin [22].

In the aspect of the powder-making process, the use of the spray dryer method is a reliable method. Because in this method natural dyes with the addition of routine and ferrulic acid copigmentation can increase the color stability in storage. Under low temperature storage conditions and dark conditions will help the powder color last longer and better [29, 42]. In the spray dryer method, the conditions of the intake temperature, the number of carriers, and also the flow rate must be considered because this affects the quality of the powder [43]. The right drying temperature can produce a good powder morphology in terms of physical yield, air powder content, solubility level which increases its color and stability. A good spray drying process is characterized by the characteristics of the powder with a moisture content below $5 \%$ and has a solubility level of $>90 \%$ [44, 45]. In the food industry, encapsulation using food-grade ingredients becomes very important. The addition of $2.5-7.5 \%$ corn powder as encapsulation to pact cactus red coloring produces a good color as a food coloring. By adjusting the condition of the spray dryer, the powder morphology can increase $75 \%$ to be better in physi- 
cal form. The copigmentation method in powder condition produces a dye that has long color resistance. With the development of research, it is possible to combine the two methods of liquid copigmentation which are then made into a powder using a spray dryer process. The combination of copigmentation agents used has also been studied. In addition, the freeze-drying process produces $77-88 \%$ encapsulation efficiency with a good level of stability. This happens because arabic gum has a very branched structure of sugar heteropolymer, glucuronic acid, and protein that allows binding of carbohydrate and maltodextrin chains and forms an effective encapsulation film [46]. Besides the particle size of the powder is influenced by the encapsulation material, because the size of this particle affects the viscosity [47]. In the application of natural dyes, to produce colors that are more vibrant and deeper without increasing the concentration of the dye can be done using chitosan (cationic).

\section{Conclusions}

The stability and brightness of natural dyes can be improved by using the copigmentation method. The method is known that there are two types used, namely liquid-liquid and powder. Almost all studies show that the copigmentation of dyes in powder form affects the stability of the resulting color. Meanwhile, the brightness of the color produced from natural dyes in liquid form is brighter. Increasing the quality of color brightness in powder form can be increased by combination of copigmentation additives and the spray dryer process configuration.

\section{References}

[1] C. Chung, T. Rojanasasithara, W. Mutilangi, and D. J. McClements, "Enhancement of colour stability of anthocyanins in model beverages by gum arabic addition," Food Chemistry, vol. 201, pp. 14-22, 2016, doi: 10.1016/j.foodchem.2016.01.051.

[2] J. Darias-Martín, M. Carrillo, E. Díaz, and R. B. Boulton, “Enhancement of red wine colour by pre-fermentation addition of copigments," Food Chemistry, vol. 73, no. 2, pp. 217-220, 2001, doi: 10.1016/S0308-8146(00)00286-7.

[3] A. A. Mariod, Enhancement of Color Stability in Foods by Gum Arabic. Elsevier Inc., 2018.

[4] M. G. Ruiz-Gutiérrez, C. A. Amaya-Guerra, A. Quintero-Ramos, E. Pérez-Carrillo, and C. O. Meléndez-Pizarro, "Use of Red Cactus Pear (Opuntia ficus-indica) Encapsulated Powder to Pigment Extruded Cereal," Journal of Food Quality, vol. 2017, 2017, doi: $10.1155 / 2017 / 7262464$.
[5] S. D. Prasetyo and C. Harsito, "Energy consumption of spray dryer machine for producing red natural powder dye and its stability Energy Consumption of Spray Dryer Machine for Producing Red Natural Powder Dye and Its Stability," vol. 030076, no. April, pp. 1-7, 2019, doi: 10.1063/1.5098251.

[6] Z. Yang, H. Peng, W. Wang, and T. Liu, "Improving the colorfastness of poly(ethylene terephthalate) fabrics with the natural dye of Caesalpinia sappan L. Wood extract and the effect of chitosan and low-temperature plasma," Journal of Applied Polymer Science, vol. 116, no. 5, pp. 2658-2667, 2008, doi: 10.1002/app.27899.

[7] C. Harsito and Suyitno, "Reducing Defects in Water-Based Paint with Natural Dyes," Journal of Engineering and Applied Sciences, vol. 13, no. 5, pp. 1291-1297, 2018, doi: 10.3923/jeasci.2018.1291.1297.

[8] Z. Idham, I. I. Muhamad, and M. R. Sarmidi, “Degradation kinetics and color stability of spray-dried encapsulated anthocyanins from Hibiscus sabdariffa L.," Journal of Food Process Engineering, vol. 35, no. 4, pp. 522-542, 2012, doi: 10.1111/j.17454530.2010.00605.x.

[9] M. Thoyib, C. Harsito, Basuki, Suyitno, and S. Hadi, "Formulating Water Based Paint with Red Natural Dyes," Journal of Advanced Research in Fluid Mechanics and Thermal Sciences, vol. 52, no. 2, pp. 259-265, 2018.

[10] S. Suyitno, T. J. Saputra, A. Supriyanto, and Z. Arifin, "Stability and efficiency of dye-sensitized solar cells based on papaya-leaf dye," Spectrochimica Acta - Part A: Molecular and Biomolecular Spectroscopy, vol. 148, pp. 99-104, 2015, doi: 10.1016/j.saa.2015.03.107.

[11] Suyitno, D. Noor Rachmad, Z. Arifin, T. Jaya Saputra, M. A. Omid, and M. Yusuf, "Effect of Natural and Synthetic Dyes on the Performance of Dye-Sensitized Solar Cells Based on ZnO Nanorods Semiconductor," Applied Mechanics and Materials, vol. 699, pp. 577-582, 2014, doi: 10.4028/www.scientific.net/amm.699.577.

[12] D. McCann et al., "Food additives and hyperactive behaviour in 3-year-old and 8/9-year-old children in the community: a randomised, double-blinded, placebo-controlled trial," Lancet, vol. 370, no. 9598, pp. 1560-1567, 2007, doi: 10.1016/S01406736(07)61306-3.

[13] B. J. Qian, J. H. Liu, S. J. Zhao, J. X. Cai, and P. Jing, "The effects of gallic/ferulic/caffeic acids on colour intensification and anthocyanin stability," Food Chemistry, vol. 228, pp. 526-532, 2017, doi: 10.1016/j.foodchem.2017.01.120.

[14] F. Weber, K. Boch, and A. Schieber, "Influence of copigmentation on the stability of spray dried anthocyanins from blackberry," LWT - Food Science and Technology, vol. 75, pp. 72-77, 2017, doi: 10.1016/j.lwt.2016.08.042.

[15] A. B. Himmetagaoglu and Z. Erbay, "Effects of spray drying process conditions on the quality properties of microencapsulated cream powder," International Dairy Journal, vol. 88, pp. 60-70, 2019, doi: 10.1016/j.idairyj.2018.08.004.

[16] F. Lao and M. M. Giusti, “The effect of pigment matrix, temperature and amount of carrier on the yield and final color properties of spray dried purple corn (Zea mays L.) cob anthocyanin powders," Food Chemistry, vol. 227, pp. 376-382, 2017, doi: 10.1016/j.foodchem.2017.01.091.

[17] M. L. Ng and R. Sulaiman, "Development of beetroot (Beta vulgaris) powder using foam mat drying," LWT - Food Science and Technology, vol. 88, pp. 80-86, 2018, doi: 10.1016/j.lwt.2017.08.032. 
[18] D. Dag, M. Kilercioglu, and M. H. Oztop, "Physical and chemical characteristics of encapsulated goldenberry (Physalis peruviana L.) juice powder," LWT - Food Science and Technology, vol. 83, pp. 86-94, 2017, doi: 10.1016/j.lwt.2017.05.007.

[19] L. Ngamwonglumlert, S. Devahastin, and N. Chiewchan, "Color and Storage Stabilities of Natural Colorant Produced from Sappan Wood," pp. 43-47, 2002.

[20] B. Zhang et al., "Colorimetric study of malvidin-3-0-glucoside copigmented by phenolic compounds: The effect of molar ratio, temperature, $\mathrm{pH}$, and ethanol content on color expression of red wine model solutions," Food Research International, vol. 102, pp. 468-477, 2017, doi: 10.1016/j.foodres.2017.09.034.

[21] T. Jiang et al., "Degradation of anthocyanins and polymeric color formation during heat treatment of purple sweet potato extract at different pH," Food Chemistry, vol. 274, pp. 460-470, 2019, doi: 10.1016/j.foodchem.2018.07.141.

[22] F. Díaz-Sánchez, E.-M. Santos-López, S. F. Kerstupp, R. Villagómez-Ibarra, and L. Scheinvar, "Colorant Extraction From Red Prickly Pear (Opuntia Lasiacantha) For Food Application," Electronic Journal of environmental, Agricultural and Food Chemistry, vol. 2, no. 5, pp. 1330-1337, 2006.

[23] P. Moser, R. T. De Souza, and V. R. Nicoletti Telis, "Spray Drying of Grape Juice From Hybrid CV. BRS Violeta: Microencapsulation of Anthocyanins Using Protein/Maltodextrin Blends as Drying Aids," Journal of Food Processing and Preservation, vol. 41, no. 1, 2017, doi: 10.1111/jfpp.12852.

[24] A. Akhtar, A. Boochani, S. M. Elahi, M. Amiri, and M. Molamohammadi, "Reflectivity and refractivity index enhancement in $\mathrm{H}$ doped ZnS graphene sheet: A first-principles study," Optik, vol. 144, pp. 446-458, 2017, doi: 10.1016/j.ijleo.2017.06.048.

[25] M. F. Al-Kuhaili, S. M. A. Durrani, A. S. El-Said, and R. Heller, "Enhancement of the refractive index of sputtered zinc oxide thin films through doping with Fe203," Journal of Alloys and Compounds, vol. 690, pp. 453-460, 2017, doi: 10.1016/j.jallcom.2016.08.165.

[26] A. El Hamidi et al., "Refractive index controlled by film morphology and free carrier density in undoped $\mathrm{ZnO}$ through sol-pH variation," Optik, vol. 158, pp. 1139-1146, 2018, doi: 10.1016/j.ijleo.2018.01.011.

[27] P. Robert, T. Gorena, N. Romero, E. Sepulveda, J. Chavez, and C. Saenz, "Encapsulation of polyphenols and anthocyanins from pomegranate (Punica granatum) by spray drying," International Journal of Food Science \& Technology, vol. 45, no. 7, pp. 13861394, Jul. 2010, doi: 10.1111/j.1365-2621.2010.02270.x.

[28] R. V Tonon, C. Brabet, and M. D. Hubinger, "Anthocyanin stability and antioxidant activity of spray-dried açai (Euterpe oleracea Mart.) juice produced with different carrier agents," Food Research International, vol. 43, no. 3, pp. 907-914, 2010, doi: https://doi.org/10.1016/j.foodres.2009.12.013.

[29] D. M. Jiménez-Aguilar, A. E. Ortega-Regules, J. D. Lozada-Ramírez, M. C. I. Pérez-Pérez, E. J. Vernon-Carter, and J. Welti-Chanes, "Color and chemical stability of spray-dried blueberry extract using mesquite gum as wall material," Journal of Food Composition and Analysis, vol. 24, no. 6, pp. 889-894, 2011, doi: https://doi.org/10.1016/j.jfca.2011.04.012.

[30] M. Fazaeli, Z. Emam-Djomeh, A. Kalbasi Ashtari, and M. Omid, "Effect of spray drying conditions and feed composition on the physical properties of black mulberry juice powder," Food and Bioproducts Processing, vol. 90, no. 4, pp. 667-675, 2012, doi: https://doi.org/10.1016/j.fbp.2012.04.006.
[31] A. Gharsallaoui, G. Roudaut, O. Chambin, A. Voilley, and R. Saurel, "Applications of spray-drying in microencapsulation of food ingredients: An overview," Food Research International, vol. 40, no. 9, pp. 1107-1121, 2007, doi: https://doi.org/10.1016/j.foodres.2007.07.004.

[32] K. Davies, "Annual Plant Reviews," in Plant pigments and their manipulation, vol. 12, no. 7, Boca Raton: CRC Press, 2004, pp. 1332-1333.

[33] A. R. Mishkin and W. S. Symbolik, "Spray Drying Process," 1971.

[34] M. R. Narayan, "Review: Dye sensitized solar cells based on natural photosensitizers," Renewable and Sustainable Energy Reviews, vol. 16, no. 1, pp. 208-215, 2012, doi: 10.1016/j.rser.2011.07.148.

[35] E. Grotewold, The Science of Flavonoids. Ohio: Springer, 2006.

[36] J. E. Brown, K. S. Gould, and Véronique Cheynier, Flavanoids: Chemistry, Biochemistry and Applications. New York: CRC Press Taylor \& Francis, 2006.

[37] K. Yoshida, S. Kitahara, D. Ito, and T. Kondo, "Ferric ions involved in the flower color development of the Himalayan blue poppy, Meconopsis grandis," Phytochemistry, vol. 67, no. 10, pp. 992998, 2006, doi: 10.1016/j.phytochem.2006.03.013.

[38] G. A. Ellested, "Structure and Chiroptical Properties of Supramolecular Flower Pigments," Chirality, vol. 18, no. 2, pp. 134-144, 2006, doi: 10.1002/chir.

[39] S. A. Mahdavi, S. M. Jafari, M. Ghorbani, and E. Assadpoor, "Spray-Drying Microencapsulation of Anthocyanins by Natural Biopolymers: A Review," Drying Technology, vol. 32, no. 5, pp. 509-518, Apr. 2014, doi: 10.1080/07373937.2013.839562.

[40] C. Chung, T. Rojanasasithara, W. Mutilangi, and D. J. McClements, "Enhanced stability of anthocyanin-based color in model beverage systems through whey protein isolate complexation," Food Research International, vol. 76, pp. 761-768, 2015, doi: 10.1016/j.foodres.2015.07.003.

[41] R. Brouillard and O. Dangles, "Anthocyanin molecular interactions: the first step in the formation of new pigments during wine aging?," Food Chemistry, vol. 51, no. 4, pp. 365-371, 1994, doi: 10.1016/0308-8146(94)90187-2.

[42] S. Ersus and U. Yurdagel, "Microencapsulation of anthocyanin pigments of black carrot (Daucus carota L.) by spray drier," Journal of Food Engineering, vol. 80, no. 3, pp. 805-812, 2007, doi: 10.1016/j.jfoodeng.2006.07.009.

[43] J. M. Obón, M. R. Castellar, M. Alacid, and J. A. Fernández-López, "Production of a red-purple food colorant from Opuntia stricta fruits by spray drying and its application in food model systems," Journal of Food Engineering, vol. 90, no. 4, pp. 471-479, 2009, doi: 10.1016/j.jfoodeng.2008.07.013.

[44] Z. Fang, R. Wang, and B. Bhandari, "Effects of Type and Concentration of Proteins on the Recovery of Spray-Dried Sucrose Powder," Drying Technology, vol. 31, no. 13-14, pp. 1643-1652, Oct. 2013, doi: 10.1080/07373937.2013.770011.

[45] M. Cano-Chauca, P. C. Stringheta, A. M. Ramos, and J. Cal-Vidal, "Effect of the carriers on the microstructure of mango powder obtained by spray drying and its functional characterization," Innovative Food Science \& Emerging Technologies, vol. 6, no. 4, pp. 420-428, Dec. 2005, doi: 10.1016/J.IFSET.2005.05.003.

[46] L. S. Kuck and C. P. Z. Noreña, "Microencapsulation of grape (Vitis labrusca var. Bordo) skin phenolic extract using gum Arabic, polydextrose, and partially hydrolyzed guar gum as encapsulating agents," Food Chemistry, vol. 194, pp. 569-576, 2016, doi: 10.1016/j.foodchem.2015.08.066. 
[47] K. Masters, Spray drying handbook., vol. 14, no. 696. London: George Godwin Ltd., 1985. 